\title{
Prevalence of and factors influencing smoking among medical and non-medical students in Tbilisi, Georgia*
}

\author{
Prevalência de tabagismo e fatores que o influenciam em estudantes de \\ medicina e outros universitários em Tbilisi, Geórgia
}

Ivane Chkhaidze, Nino Maglakelidze, Tamaz Maglakelidze, Nikolai Khaltaev

\begin{abstract}
Objective: Smoking is a serious problem that has a devastating impact on health. The objective of this study was to describe the prevalence of and factors influencing smoking among medical and non-medical students in Tbilisi, Georgia, as well as to determine whether medical education has an impact on smoking. Methods: A cross-sectional study was carried out at Tbilisi State Medical University and Tbilisi State University, both of which are located in Tbilisi, Georgia. A total of 400 4th-year students (200 students at each university) were asked to complete standardized questionnaires. Results: Of the sample as a whole, $48.75 \%$ were identified as smokers and $51.25 \%$ were identified as nonsmokers. The mean age was 20.24 years among smokers and 20.26 years among nonsmokers. Of the medical students, $49.5 \%$ were smokers, as were $48.0 \%$ of the non-medical students. The male-to-female ratio in the study population was 0.9:1.1. Smoking was found to have a strong relationship with gender, males accounting for $65 \%$ of all smokers. Of the smokers, 56.9\% stated that they would like to quit smoking (for health or financial reasons). Of the medical students, 59.5\% expressed a willingness to quit smoking, as did 54.2\% of the non-medical students. Conclusions: There is a need to improve smoking education for undergraduate students. Special attention should be given to the inclusion of anti-smoking education in undergraduate curricula, as well as to the implementation of smoking prevention campaigns at institutions of higher education. However, such measures will be effective only if tobacco control policies are strictly enforced on the national level as well.
\end{abstract}

Keywords: Attitude to Health; Smoking; Students, Medical; Prevalence.

\section{Resumo}

Objetivo: 0 tabagismo é um problema sério, cujo impacto na saúde é devastador. 0 objetivo deste estudo foi descrever a prevalência do tabagismo e os fatores que o influenciam em estudantes de medicina e outros universitários em Tbilisi, Geórgia, bem como determinar se a educação médica tem impacto no tabagismo. Métodos: Foi realizado um estudo transversal na Universidade Médica Estadual de Tbilisi e na Universidade Estadual de Tbilisi, ambas em Tbilisi, Geórgia. Pedimos a 400 alunos de quarto ano (200 em cada universidade) que respondessem a questionários padronizados. Resultados: Do total da amostra, 48,75\% eram fumantes e $51,25 \%$ eram não fumantes. A média de idade dos fumantes foi de 20,24 anos e a dos não fumantes foi de 20,26 anos. Dos estudantes de medicina, 49,5\% eram fumantes, assim como o eram 48,0\% dos universitários que não estudavam medicina. A razão entre os gêneros masculino e feminino foi de 0,9:1,1. 0 tabagismo apresentou forte relação com o gênero; 65\% dos fumantes eram do sexo masculino. Dos fumantes, 56,9\% disseram que gostariam de parar de fumar (por motivos de saúde ou financeiros). Dos estudantes de medicina, 59,5\% disseram que estavam dispostos a parar de fumar, assim como o disseram 54,2\% dos universitários que não estudavam medicina. Conclusões: É preciso melhorar a educação sobre o tabagismo nas universidades. Deve-se dar atenção especial à inclusão de educação antitabagismo no currículo das universidades e à implantação de campanhas de prevenção ao tabagismo em instituições de ensino superior. Entretanto, essas medidas só serão eficazes se as políticas de controle do tabaco forem rigorosamente observadas também em nível nacional.

Descritores: Atitude Frente a Saúde; Tabagismo; Estudantes de Medicina; Prevalência.

\footnotetext{
* Study carried out at Tbilisi State Medical University, Tbilisi, Georgia.

Correspondence to: Ivane Chkhaidze, MD, PhD, Professor, Tbilisi State Medical University, 33, Vazha Pshavela Av., Tbilisi, Georgia. Tel. 9957754189 12. E-mail: ivane_ch@internet.ge

Financial support: None.

Submitted: 11 October 2012. Accepted, after review: 19 August 2013.
} 


\section{Introduction}

Despite its terrifying impact on health, tobacco use is widespread throughout the world. If no effective interventions are introduced and implemented against it, up to one billion people will die from tobacco use in the 21st century. ${ }^{(1)}$

Special focus is directed toward youth smoking. Most smokers start smoking during adolescence or right after high school graduation. ${ }^{(2)}$ Youth smoking is a concern for industrial, low-income, and middle-income countries, and there is no significant difference between the genders regarding the prevalence of smoking. ${ }^{(3,4)}$

In 2000, Decree no. 412 ("On Measures for Tobacco Control and Prevention in Georgia”), issued by the President of Georgia, came into force, and the World Health Organization (WHO) Framework Convention on Tobacco Control was signed in 2004; however, the smoking rate in Georgia remains high and tends to increase, especially among youth. ${ }^{(5)}$

There are approximately 5,000 undergraduate students currently enrolled in Tbilisi State Medical University (located in the city of Tbilisi, Georgia) and approximately 18,000 currently enrolled in Tbilisi State University (also in Tbilisi, Georgia). The objectives of the present study were to determine the prevalence of smoking in medical and non-medical students at the abovementioned universities; to determine whether medical education has an impact on smoking; and to identify the most important risk factors for smoking among undergraduate students.

\section{Methods}

Participation in the study was voluntary. The purpose of the survey was explained to the students, who were subsequently asked to complete anonymous questionnaires. We attempted to survey all available students without using any randomization schemes.

Because the present study was a cross-sectional study conducted during or immediately after an open, general lecture, it was difficult to predict who would be attending the lecture. Therefore, for practical purposes, 200 students (100 males and 100 females) at each university were interviewed during the study period.

Smoking status was established in accordance with the WHO criteria. ${ }^{(6)}$ Respondents who reported smoking at least 1 cigarette per day (either every day or occasionally) were defined as current smokers. Those who had been experimenting with smoking at the time of the survey (having had fewer than 100 cigarettes in their lifetime) were also defined as smokers. Those who had never smoked or who had smoked fewer than 100 cigarettes in their lifetime but who had not smoked within the past 30 days (including the day of the survey) were defined as nonsmokers. Smokers were asked about the average number of cigarettes smoked daily, age at smoking initiation, and attempts to quit, if any.

Data collection took place at the two universities during the study semester, between February and March of 2011. The smoking questionnaire employed in the WHO Multinational Monitoring of Trends and Determinants in Cardiovascular Disease Project ${ }^{(7)}$ was modified to reflect local habits and features. The final version of the structured questionnaire included multiple-choice questions and several open questions addressing smoking status, nicotine dependence, and factors influencing smoking behavior, as well as knowledge and perceptions of smoking.

We used the Statistical Package for the Social Sciences, version 15.0 for Windows (SPSS Inc., Chicago, IL, USA), in order to calculate the frequencies of each variable. ${ }^{(8)}$ Pearson's chi-square test was used for comparing proportions, and the Student's t-test was used in order to examine the differences among the means. Logistic regression analyses were used in order to determine whether smoking was correlated with demographic and health risk behavior characteristics.

\section{Results}

The male-to-female ratio in the study population was 0.9:1.1 (190 males vs. 210 females). The mean age was 20.24 years (range, 17-27 years) among smokers and 20.26 years (range, 17-25 years) among nonsmokers. There were no significant differences in the distribution of age, gender, and year of education among the students.

On the basis of daily cigarette consumption, smokers were defined as follows: very heavy smokers (> 20 cigarettes/day); moderate-toheavy smokers (11-20 cigarettes/day); or light smokers (1-10 cigarettes/day). Of the 195 students who answered that question, 45.8\% 
were light smokers, $40.2 \%$ were moderate to heavy smokers, and $14.0 \%$ were very heavy smokers (Table 1). Smoking was found to have a strong relationship with gender, males accounting for $65 \%$ of all smokers and females accounting for $35 \%$.

Smokers were asked whether they had attempted to quit smoking. Of the 195 smokers, $122(62.6 \%)$ stated that they had never attempted to quit. Among those who stated that they had attempted to quit smoking, the most common reasons for starting to smoke again were smoking addiction, alcohol consumption, and other external factors (students being unable to specify such factors).

Smokers were also asked whether they were willing to quit smoking. Of the 195 smokers, 111 (56.9\%) stated that they were, whereas $43.1 \%$ stated that they were not.

We found no statistically significant differences between medical and non-medical students in terms of the prevalence of smoking (Table 2). In addition, the chi-square test showed no statistically significant relationship between the type of education (medical or non-medical) and the smoking status.

Of the medical students, 59.5\% expressed willingness to quit smoking, as did $54.2 \%$ of the non-medical students (Table 3). The difference was not statistically significant.

The main reasons for being willing to quit were quite similar between medical and non-medical students, with no statistically significant differences between the two groups. In fact, health reasons were slightly more common among non-medical students.

Smokers were asked whether an increase in the price of tobacco would be an incentive to quit smoking. Of the smokers, 69.2\% stated that they would not quit smoking if the price of cigarettes increased and 30.8\% stated that they would $(p<0.001)$. We found no difference between medical and non-medical students in terms of the high price of tobacco being a motivation for quitting smoking.

Of the sample as a whole, $65 \%$ had relatives who were smokers and 35\% were living with nonsmokers. However, the chi-square test showed that having smokers in the family had no significant influence on the smoking habits of the students.
Table 1 - Prevalence and frequency of smoking among the students interviewed $(\mathrm{n}=400)$.

\begin{tabular}{lc}
\hline Smoking status & $\mathrm{n}(\%)$ \\
\hline Nonsmokers & $205(51.25)$ \\
\hline Smokers & $195(48.75)$ \\
\hline $\begin{array}{l}\text { Light smokers } \\
\text { (1-10 cigarettes/day) }\end{array}$ & $86(21.50)$ \\
& $\begin{array}{l}\text { Moderate-to-heavy smokers } \\
\text { (11-20 cigarettes/day) } \\
\text { Very heavy smokers } \\
\text { (> 20 cigarettes/day) }\end{array}$ \\
\hline
\end{tabular}

Table 2 - Smoking prevalence, by type of education.

\begin{tabular}{lcc}
\hline & \multicolumn{2}{c}{ Do you smoke? } \\
\cline { 2 - 3 } Type of education & $\mathrm{yes}$ & No \\
Medical $(\mathrm{n}=200)$ & $99(49.5)$ & $\mathrm{n}(\%)$ \\
\cline { 2 - 3 } Non-medical $(\mathrm{n}=200)$ & $96(48.0)$ & $104(51.5)$ \\
\hline
\end{tabular}

Table 3 - Willingness to quit smoking, by type of education.

\begin{tabular}{lcc}
\hline & \multicolumn{2}{c}{$\begin{array}{c}\text { Would you like } \\
\text { to quit smoking? }\end{array}$} \\
\cline { 2 - 3 } Type of education & $\mathrm{n}(\%)$ & $\mathrm{n}(\%)$ \\
\cline { 2 - 3 } Medical $(\mathrm{n}=99)$ & $40(40.4)$ & $59(59.5)$ \\
Non-medical $(\mathrm{n}=96)$ & $44(45.8)$ & $52(54.2)$ \\
\hline
\end{tabular}

\section{Discussion}

The present study showed a high prevalence of smoking among undergraduate students in Georgia, smokers accounting for $48.75 \%$ of the study population. Our findings also show that smoking was strongly associated with gender, males accounting for 65\% of all smokers and females accounting for 35\%. In Georgia, male and female smokers account for 56\% and 6\% of the general adult population, respectively. ${ }^{(9)}$

We found no statistically significant differences between medical and non-medical students in terms of the prevalence of smoking (49.5\% vs. $48.0 \%$ ). A similar study was conducted in Greece, which is the country with the highest per capita consumption of cigarettes in the European Union. The prevalence of smoking in that study was $26-56 \%$ for medical students and $44-57 \%$ for non-medical students. The results of that study are consistent with ours and suggest that medical education has little impact on student 
decisions regarding whether or not to smoke. (10) Several other authors have reported results that are also in accordance with those of the present study, having reported smoking prevalence rates as high as $47 \%$ in medical students and even higher among non-medical students. ${ }^{(11,12)}$ Although attempts at conducting similar studies have focused exclusively on medical students, ${ }^{(12,13)}$ most such studies have shown high rates of smoking. ${ }^{(14)}$ This can be seen as an indicator of lax enforcement of anti-tobacco measures at universities, as well as being an indicator of lax government policies directed toward reducing tobacco consumption in the general population.

A study conducted in Brazil showed that the prevalence of smoking among medical students was high and that medical students had insufficient knowledge of smoking. ${ }^{(15)}$ However, several studies have shown declining trends in the prevalence of smoking, especially among medical students. ${ }^{(16-18)}$ The results of a study conducted in the University of Jordan, in the city of Amman, Jordan, corroborate these findings, having shown a lower prevalence of smoking among health science students. ${ }^{(16)}$ Similar findings were reported in a study conducted in 1995 and involving students at the University of Cambridge, in the city of Cambridge, England. ${ }^{(17)}$ That study showed that the prevalence of smoking was higher among students in the humanities than among medical students (17\% vs. 7.7\%). These data reinforce the notion that those studying health-related subjects have a higher level of awareness of the dangers of smoking. ${ }^{(18)}$ However, it is of note that various smoking prevalence studies conducted in other countries have shown characteristics that are different from those found in Brazil, Jordan, or England. Nevertheless, there have been few studies comparing medical and non-medical students in terms of trends in smoking. Therefore, it is difficult to determine whether the trend toward a reduction in smoking prevalence is due to anti-smoking education in the medical curriculum.

The results of our study show that the prevalence of smoking is alarmingly high, indicating that current medical curricula do not place enough emphasis on the hazards of smoking. In fact, inadequate undergraduate education about tobacco-related health risks has been reported to be one of the main factors contributing to missed opportunities. ${ }^{(19)}$ In addition, most studies involving the general population, as well as most of those involving health professionals, ${ }^{(20-22)}$ have shown that tobacco consumption is more common in males. Although the prevalence of smoking has been decreasing in males and increasing in females, it remains significantly higher in males. ${ }^{(21)}$

Our results regarding the proportion of students who had attempted to quit smoking at least once seem to be quite similar to those of the study conducted in Greece, ${ }^{(9)}$ according to which $44 \%$ of all medical students and 36\% of all non-medical students had attempted to quit at least once. These findings show that undergraduate students have poor knowledge of the negative health effects of smoking and indicate the need for educational programs that are more comprehensive, as well as for smoking cessation programs targeting such students.

We sought to determine how many students were willing to quit smoking and why they were willing to quit. We found that $56.9 \%$ of the smokers were willing to quit, health and financial reasons being the most common reasons for quitting.

Of the medical students, 59.5\% expressed willingness to quit smoking, as did $54.2 \%$ of the non-medical students. Although the difference is not statistically significant, it suggests that medical students have a better understanding of the harmful effects of tobacco. Nevertheless, medical and non-medical students gave similar reasons for quitting smoking.

Medical education appears to have no preventive effect, or rather, has no influence on the attitudes and behaviors of undergraduate students toward smoking. In any case, it is vital to improve anti-smoking education in the curricula of all medical and non-medical schools. In the case of medical students, it should be borne in mind that they will become physicians. As such, they are expected to play a crucial role in antismoking campaigns. This means that they will not only advise patients on smoking issues but will also serve as role models for their patients. Therefore, the undergraduate years provide a perfect opportunity for making medical students fully aware of the harmful effects of smoking. The proportion of students who are actually willing to quit smoking can serve as a very good indicator of success in quitting.

Our study showed a high prevalence of smoking among undergraduate students in Georgia. The results indicate that current medical education 
is ineffective in making students aware of the hazards of smoking and in advocating smoking cessation among students.

Although the proportion of male smokers is higher than is that of female smokers, the proportions of males and females expressing willingness to quit smoking are equal. The lack of significant difference between medical and non-medical students regarding willingness to quit smoking suggests a lack of knowledge of the harmful effects of smoking and emphasizes the need to revise existing educational programs. An increase in the price of cigarettes is not enough to reduce the prevalence of smoking. Therefore, anti-tobacco campaigns that are more intensive are required.

\section{References}

1. World Health Organization [homepage on the Internet]. Geneva: World Health Organization [cited 2012 Sep 19]. Tobacco. Fact Sheet. №339, May 2012. Available from: http://www.who.int/mediacentre/factsheets/fs339/ en/index.html

2. Precioso J, Samorinha C, Macedo M, Antunes H. Smoking prevalence in Portuguese school-aged adolescents by gender: can we be optimistic? [Article in Portuguese]. Rev Port Pneumol. 2012;18(4):182-7. http://dx.doi. org/10.1016/j.rppneu.2012.03.001 PMid:22542095

3. World Health Organization [homepage on the Internet]. Geneva: World Health Organization [cited 2012 Sep 19]. About Youth and tobacco. Available from: http://www. who.int/tobacco/research/youth/about/en/index.html

4. World Health Organization [homepage on the Internet]. Geneva: World Health Organization [cited 2012 Sep 19]. Health Effects of Smoking Among Young People. Available from: http://www.who.int/tobacco/research/ youth/health_effects/en/index.html

5. Bakhturidze G, Kobeshavidze G. Tobacco Consumption and Health Damages in Georgia. Available from: http:// www.fctc.org.ge/?lang $=$ eng\&go $=$ resources

6. World Health Organization. Guidelines for Controlling and Monitoring the Tobacco Epidemic. Geneva: World Health Organization; 1998.

7. World Health Organization [homepage on the Internet]. Geneva: World Health Organization. [cited 2012 Sep 19]. MONICA Project. Smoking Questionnaire. Available from: http://www.ktl.fi/publications/monica/manual/index.htm

8. SPSS Inc. SPSS Base 15.0 User's Guide. Chicago: SPSS Inc.; 2006.

9. World Health Organization [homepage on the Internet]. Geneva: World Health Organization [cited 2012 Sep 19]. WHO report on the global tobacco epidemic, 2011: warning about the dangers of tobacco. Available from: http://www.who.int/tobacco/global_report/2011/en/

10. Alexopoulos EC, Jelastopulu E, Aronis K, Dougenis D. Cigarette smoking among university students in Greece: a comparison between medical and other students.
Environ Health Prev Med. 2010;15(2):115-20. http:// dx.doi.org/10.1007/s12199-009-0110-0 PMid:19802656 PMCid:PMC2824102

11. Mammas IN, Bertsias GK, Linardakis M, Tzanakis NE, Labadarios DN, Kafatos AG. Cigarette smoking, alcohol consumption, and serum lipid profile among medical students in Greece. Eur J Public Health. 2003;13(3):278-82. http://dx.doi.org/10.1093/eurpub/13.3.278 PMid:14533734

12. Xiang H, Wang Z, Stallones L, Yu S, Gimbel HW, Yang P. Cigarette smoking among medical college students in Wuhan, People's Republic of China. Prev Med. 1999;29(3):210-5. http://dx.doi.org/10.1006/ pmed.1999.0525 PMid:10479609

13. Yang G, Fan L, Tan J, Qi G, Zhang Y, Samet JM, et al. Smoking in China: findings of the 1996 National Prevalence Survey. JAMA. 1999;282(13):1247-53. http:// dx.doi.org/10.1001/jama.282.13.1247 PMid:10517427

14. Vakeflliu Y, Argjiri D, Peposhi 1, Agron S, Melani AS. Tobacco smoking habits, beliefs, and attitudes among medical students in Tirana, Albania. Prev Med. 2002;34(3):370-3. http://dx.doi.org/10.1006/ pmed.2001.0994 PMid:11902854

15. Botelho C, Silva AM, Melo CD Smoking among undergraduate health sciences students: prevalence and knowledge. J Bras Pneumol. 2011;37(3):360-6. http://dx.doi.org/10.1590/S1806-37132011000300013 PMid:21755192

16. Haddad LG, Malak MZ. Smoking habits and attitudes towards smoking among university students in Jordan. lnt J Nurs Stud. 2002;39(8):793-802. http://dx.doi. org/10.1016/S0020-7489(02)00016-0

17. Willcox ML. Tobacco control programmes for universities: a feasibility study. J Public Health Med. 1997;19(1):3744. http://dx.doi.org/10.1093/oxfordjournals.pubmed. a024585 PMid:9138215

18. Baska T, Straka S, Mad'ar R. Smoking habits in university students in Slovakia. Cent Eur J Public Health. 2000;8(4):245-8. PMid:11125981

19. Steptoe A, Wardle J, Cui W, Bellisle F, Zotti AM, Baranyai $\mathrm{R}$, et al. Trends in smoking, diet, physical exercise, and attitudes toward health in European university students from 13 countries, 1990-2000. Prev Med. 2002;35(2):97104. http://dx.doi.org/10.1006/pmed.2002.1048 PMid:12200093

20. Öztürk C, Bektaş M, Yilmaz E, Salman F, Şahin T, İlmek M, et al. Smoking status of Turkish nursing students and factors affecting their behavior. Asian Pac J Cancer Prev. 2011;12(7):1687-92. PMid:22126545

21. Monteiro CA, Cavalcante TM, Moura EC, Claro RM, Szwarcwald CL. Population-based evidence of a strong decline in the prevalence of smokers in Brazil (1989-2003) Bull World Health Organ. 2007;85(7):527-34. http:// dx.doi.org/10.2471/BLT.06.039073 PMid:17768501 PMCid:PMC2636372

22. Musmar SG. Smoking habits and attitudes among university students in Palestine: a cross-sectional study. East Mediterr Health J. 2012;18(5):454-60. PMid:22764431 


\section{About the authors}

\section{Ivane Chkhaidze}

Professor of Pediatrics, Tbilisi State Medical University; and Medical Director, lashvili Central Children's Hospital, Tbilisi, Georgia.

\section{Nino Maglakelidze}

Physician. Georgia National Center for Disease Control, Tbilisi, Georgia.

\section{Tamaz Maglakelidze}

Head. Department of Pulmonology, EUROMEDCENTER, Tbilisi, Georgia.

\section{Nikolai Khaltaev}

Vice-Chair. World Health Organization Global Alliance against Chronic Respiratory Diseases, Geneva, Switzerland. 